\title{
Interspecific variation in deterioration and degradability of avian feathers: The evolutionary role of microorganisms
}

Manuel Azcárate-García ${ }^{1}$, Sonia González-Braojos², Silvia Díaz-Lora ${ }^{3}$, Magdalena Ruiz-Rodríguez ${ }^{1}$, Manuel Martín-Vivaldi ${ }^{3,4}$, Manuel MartínezBueno $^{4,5}$, Juan Moreno ${ }^{2}$ \& Juan José Soler ${ }^{1,4 *}$

${ }^{1}$ Departamento de Ecología Funcional y Evolutiva, Estación Experimental de Zonas Áridas (EEZA-CSIC), Almería. Spain.

$1{ }^{2}$ Departamento de Ecología Evolutiva, Museo Nacional de Ciencias Naturales (MNCN-CSIC), Madrid. Spain.

${ }^{3}$ Departamento de Zoología, Facultad de Ciencias, Universidad de

${ }^{5}$ Departamento de Microbiología, Facultad de Ciencias, Universidad de

${ }^{4}$ Unidad Asociada Coevolución: Cucos, Hospedadores y Bacterias Simbiontes, Universidad de Granada, E-18071 Granada, Spain Granada, Granada. Spain. 
25 Abstract

26 Feathers are essential for avian life, and factors affecting their integrity are important to understand their evolution. These factors should depend on, among other traits, species-specific bacterial environments and life-history characteristics. However, interspecific variation in feather deterioration, feather susceptibility to degradation by keratinolytic bacteria (degradability), and bacterial environment, have rarely been quantified. Here, we did so by measuring deterioration and degradability of wing feathers of fledglings in 16 bird species, and characterizing the bacterial environment where they developed. We found statistically significant interspecific variation for all considered variables. On average, non-melanised were more deteriorated than melanised feathers, but differences depended on the species. Moreover, nest bacterial loads were related to feathers wear, but the sign of the preponderant role of bacteria in driving the evolution of avian feathers.

45 Keywords: Feather degrading bacteria, Feather wear, Interspecific comparisons, Keratinolytic bacteria, Nest bacterial environment. 


\section{Introduction}

The presence of feathers is one of the defining characteristics of the Class Aves and has historically attracted the attention of evolutionary biologists trying to understand the extremely high variation in avian morphology, structure and coloration (Hanson 2011). Classic adaptive explanations for the existence of feathers include insulation (i.e., thermoregulation or waterproofing) and flight (Rayner 1988, Stettenheim 2000), but they also function in different scenarios of social communication and sexual selection (Andersson 1994, Møller et al. 1998, Senar 2006, Hanson 2011, Roulin 2016). Thus, feather characteristics providing the holder with advantages in the above mentioned scenarios have been studied as possible key adaptations driving the evolution of birds (Rayner 1988, Stettenheim 2000).

Factors affecting the integrity of feathers are therefore important to understand their evolution. Feather integrity might for instance depend on physiological conditions of individuals during feather growth, which could result in feather malformations (e.g. fault bars) that enhance feather deterioration and breakage (Jovani and Rohwer 2017). Among factors directly promoting feather damage, the physical abrasive wear due to friction while flying or diving, or deterioration due to contacts with distinct materials while walking or perching, are well known since many years (Francis and Wood 1989, Swaddle et al. 1996). Chemical abrasion of feathers has also received attention, especially during the last decade, focussing on that induced by keratinase-producing bacteria (Gunderson 2008). All these factors negatively affect feather integrity and, thus, their functioning in thermoregulation, communication and flight, resulting in severe fitness consequences. Risk of feather deterioration would in any case depend on life style or life history characteristics such as migratory or foraging behaviours (Møller et al. 2012). This scenario therefore raises the expectation that the 
76 degree of feather deterioration should be a species-specific character, a 77 prediction that to the best of our knowledge has never been explored.

Feather degradation by keratinolytic bacteria occurs in wild birds (Leclaire et al. 2014, Kent and Burtt 2016, but see Cristol et al. 2005), which for instance, might have consequences in scenarios of sexual selection (Shawkey et al. 2007, 2009, Ruiz-Rodríguez et al. 2015) and survival (Møller et al. 2012). Moreover, bacterial communities of avian feathers vary interspecifically (Javůrková et al. 2019). Detecting evidence of interspecific variation in feather wear in standard conditions could suggest the existence of interspecific variation in environmental factors associated with the risk of feather deterioration, including bacterial environment (Kent and Burtt 2016). Moreover, since these environmental factors likely vary among species (see above), natural selection could have favoured the evolution of characteristics that counteract or reduce feather degradation by keratinolytic bacteria in environments that are distinctive of each species (Burtt 2009, Burtt et al. 2011, Javůrková et al. 2019). If this was the case, we should find interspecific variation in traits functioning in preventing feathers' wear (Burtt 2009) such as feather susceptibility to degradation by keratinolytic bacteria (hereafter, feather degradability) (Ruiz-de-Castaneda et al. 2015, Ruiz-de-Castañeda et al. 2012, Ruiz-Rodríguez et al. 2016).

The structure and chemical composition of feathers are known to affect feather wear of wild birds (Ruiz-de-Castañeda et al. 2012). Although the main chemical component of feathers is $\beta$-keratine, a slight variation in pigment composition may influence feather degradability. We know for instance that indentation hardness of melanic keratin is greater than that of non-melanic keratin (Bonser 1995), and that rates of wear (Burtt 1979) and of breakage (Kose and Møller 1999) are lower in melanic than in nonmelanic feathers. Furthermore, melanised feathers resist bacterial 
104 degradation better than pale, unmelanised feathers (Goldstein et al. 2004, 105 Gunderson et al. 2008, Ruiz-de-Castañeda et al. 2012). Moreover, in 106 comparisons with pale birds, dark birds often live in humid habitats (Delhey 2017), where more active feather degrading bacilli are abundant (Burtt and Ichida 2004), which suggests a link between habitat-related risk of feather degradation and feather characteristics that reduce such a risk. This scenario therefore suggests that, because birds should compensate by strengthening their feathers (Schreiber et al. 2006, Ruiz-de-Castañeda et al. 2012), feather degradability should vary between melanised and unmelanised feathers within the same species, and that a considerable interspecific variation should exist in such feather characteristics. Although variation in degradability has been studied intraspecifically in relation to feather pigmentation (Burtt et al. 2011, Ruiz-de-Castañeda et al. 2012) and habitat characteristics (Ruiz-Rodríguez et al. 2016), interspecific variation in feather degradability has only been explored for 13 parrot species (Burtt et al. 2011).

Here, we have quantified intra and interspecific variation in feather wear of nestlings' birds close to abandoning the nest (hereafter fledglings). We did so by microscopically quantifying deterioration of wing feathers, mostly secondary-covert-wing feathers, in 16 species of birds. We also estimated feather degradability by quantifying keratin degradation by the well-known feather degrading bacterium Bacillus licheniformis (Kent and Burtt 2016). We expected to find significant interspecific variation in feather wear and in feather degradability, and that these two traits would positively covary interspecifically. By using feathers of nestlings we restricted (i.e., standardized) factors that could have affected feather deterioration state to those occurring within the nest environment. Moreover, independently of the altricial bird species, feathers of nestlings close to abandon the nests are at a similar state of development and, thus, are interspecifically comparable. 
132 Nestling feathers are often of lower quality than adult feathers (Callan et al. 133 2019). Nestling feathers might play pivotal roles in social communication

134 during nestling (Morales et al. 2019) and post-fledging periods (Moreno and Soler 2011), and even explain probability of predation (Callan et al. 2019) and body condition (Minias et al. 2015) during the post-fledging and first winter periods. Thus, although post-juvenile moult is likely related to quality of fledgling feathers (Minias et al. 2015), exploring factors affecting integrity of nestling feathers is important to understand factors affecting their survival.

Within nests, the bacterial environment would largely determine feather bacterial loads (Jacob et al. 2018) and, thus, risk of bacterial degradation of feathers. Nest bacterial environment are largely determined by the behaviour of parents including those related to nest building (e.g., nest materials used) (Ruiz-Castellano et al. 2016, 2017, 2019), nest sanitation (e.g., nestling faeces removal) (Soler et al. 2015, Azcárate-García et al. 2019) and incubation (Ruiz-Castellano et al. 2019). Consequently, selection pressures acting on feather degradation during the nestling phase differ from those acting after abandoning the nest. Previous studies have detected interspecific variation in nest bacterial environments by sampling the microbiome of the eggshells of different species (Peralta-Sánchez et al. 2018). Moreover, interspecific variation in eggshell bacterial load is associated with life history characteristics (Peralta-Sánchez et al. 2012) and, thus, it is possible that nest bacterial environments determine wear and degradability of nestling feathers. Here, we characterised bacterial loads of the same nests where we collected nestling feathers to evaluate their deterioration state. However, the effects of nest bacterial environments on feather wear is not straightforward. It for instance depends on the presence of bacteria with keratinolytic activity (i.e. able to degrade feather tissue) that will positively affect feather deterioration. Antimicrobial activity (against 
160 feather-degrading bacteria) of bacteria within the nest community would also 161 determine feather degradation; the higher the density of these bacteria the lower the effect on feather deterioration. Finally, it is also possible that the physical structure of feathers was adapted to species-specific nest bacterial communities, which might result in these two variables being not related to each other at the interspecific level. Thus, we explored the association of nest bacterial density with feather deterioration and degradability by distinguishing different groups of bacteria.

\section{Material and Methods}

Study areas and fieldwork

Fieldwork were carried out in the Hoya de Guadix $\left(37^{\circ} 18^{\prime} \mathrm{N} ; 3^{\circ} 11^{\prime} \mathrm{W}\right)$, southern Spain, and in the forest of Valsaín (40⒌' $\left.\mathrm{N}, 04^{\circ} 01^{\prime} \mathrm{W}\right)$, central Spain, during the 2015 and 2016 breeding seasons. For a detailed description of the southern and central Spain study areas see Martín-Vivaldi et al. (2006), Soler and Avilés (2010), and González-Braojos et al. (2017). We collected information for 16 species that included hole and non-hole nesting species (Table 1). The nests of hole-nesting species were mostly located within nest boxes installed in the study areas, while nests of the other species were found by systematic search of appropriate habitats within the study areas. Samples (wing feathers and nest bacterial samples) were collected at a standard relative age during their ontogeny when less than $10 \%$ of the primary feathers were covered by the cylindrical sheaths (i.e., when they were in the last fifth of its normal nestling development, close to abandoning the nest). Moreover, for a subsample of species, we captured adults during the breeding season and collect the same kind of feathers than in nestlings. We used these samples to validate the use of nestling feathers to explore interspecific differences in feather characteristics. 
We collected a minimum of two wing feathers of at least two randomly selected nestlings in each sampled nest. For most sampled species, we collected the third secondary covert feathers. Whenever possible, we collected wing feathers that had both dark (i.e., with relatively high concentration of eu- and/or pheo-melanin) and pale (i.e., with relatively low, if any, concentration of eu- and/or pheo-melanin) areas, or different feathers that were either dark or pale. Feather darkness is usually related to presence of melanin (Goldstein et al. 2004, Gunderson et al. 2008, Ruiz-de-Castañeda et al. 2012) and, thus, we call them as melanised and non-melanised feathers, respectively. To cut the feathers at the upper part of the quill (to avoid bleeding) we used scissors previously washed with 95\% ethanol and disinfected with a Bunsen burner. Feathers of each nestling were kept in new zipper plastic bags and stored in the lab at dark and $4{ }^{\circ} \mathrm{C}$ until the analyses within the following ten months. The same day of feather collection, during the last days of the nesting period, we sampled nest bacterial loads by gently rubbing the nest-cup material, or nest surface where nestlings were located, with a sterile swab (Sterile R, Nuova Aptaca S.R.L.) slightly wetted with sterile sodium phosphate buffer $(0,2 \mathrm{M} ; \mathrm{pH}=7,2)$ during 10 seconds. Meanwhile, nestlings were kept in a cotton bag. Afterwards, we kept the swab in a microcentrifuge tube with $1.2 \mathrm{ml}$ of phosphate buffer at $4-6{ }^{\circ} \mathrm{C}$, in a portable refrigerator until being processed in the lab within the next 4 days.

Feather wear

The level of feather wear was estimated following the protocol described in Ruiz-Rodríguez et al. (2015). Briefly, feathers were examined and photographed (2x) under a binocular lens (Nikon SMZ1500, Melville, NY, USA) connected to a camera (Nikon Digital Sight DS Fi1). Measurements from pictures were taken using the software NIS Elements F 3.1. Following 
216 Ruiz-Rodríguez et al. (2015), we considered: (i) whether or not the tip of the

217 feather was incomplete; (ii) the length $(\mathrm{mm})$ of the feather tip that showed 218 clear signs of wear (apical part); and (iii) the number of barbules that were degraded in 20 randomly chosen barbs of the basal part (see Figure 3 in RuizRodríguez et al. (2015)). Wear levels were ranked from 0 (no degradation) to 3 (more than $2 / 3$ of the feather damaged). Two lab technicians, who were unaware of the feather origin (i.e., species) or hypotheses tested, evaluated all photographs. Whenever possible, we distinguished wear of melanised and of unmelanised feathers (or parts of the same feather). Repeatability of visual estimations was calculated by comparing both assessments in a one-way ANOVA. Repeatability was relatively high $(\mathrm{F}=7.32$, df $=2599,2600, \mathrm{P}<$ 0.0001 , repeatability index $=0.76$ ). Feather wear varied significantly among nests of the same species (GLM, effect of nest identity nested within species identity, $\mathrm{F}=1.88, \mathrm{df}=151,177.8, \mathrm{P}<0.001$ ), but not among nestlings within the same nest (GLM, effect of nestling identity nested within nest and species identities, $\mathrm{F}=0.99, \mathrm{df}=227,1648, \mathrm{P}=0.53$ ). Thus, we used average values of evaluated feathers from the same nest in subsequent analyses.

\section{Feather degradability}

235

236

237

238

239

240

241

242

Feather degradability was explored by using complete feathers and following the protocol described elsewhere (Ruiz-Rodríguez et al. 2015, RuizRodríguez et al. 2009, Gunderson et al. 2008, Ruiz-de-Castañeda et al. 2012). It is worth mentioning here that because degradability was estimated for complete feathers, we were not able to distinguish between degradability of the pigmented and non-pigmented parts of feathers. Moreover, because pigmentation (melanised vs non-melanised) of the collected wing feathers does not vary within species, we did not contemplate pigmentation as a factor 
when analysing possible interspecific differences in feather degradation. Finally, a single feather per sampled nests were analysed.

A brief description of the protocol is as follows: Previously separated and weighed feathers were sterilized in the autoclave before the experiment. Afterward, each feather was included in a previously sterilized experimental glass tube containing $4 \mathrm{~mL}$ of a PBS buffer $\left(9.34 \mathrm{mM} \mathrm{NH}_{4} \mathrm{Cl}, 8.55 \mathrm{mM}\right.$ $\mathrm{NaCl}, 1.72 \mathrm{mM} \mathrm{K} \mathrm{HPO}_{4}, 2.92 \mathrm{mM} \mathrm{KH} \mathrm{PO}_{4}, 0.49 \mathrm{mM} \mathrm{MgCl}_{2}-6 \mathrm{H}_{2} \mathrm{O}$ and $0.01 \%$ yeast extract in $100 \mathrm{~mL}$ of distilled water). Moreover, a colony of Bacillus licheniformis D13 previously isolated from TSA plates was introduced in each of the experimental glasses with a sterile loop. After vortexing, we collected $1 \mathrm{~mL}$ from each tube as a basal measurement, and kept it at $4{ }^{\circ} \mathrm{C}$ until measurement in the spectrophotometer. Experimental tubes were incubated at $37{ }^{\circ} \mathrm{C}$ in constant agitation at $120 \mathrm{rpm}$ in an orbital agitator (VWR, Spain). $1 \mathrm{~mL}$ was collected from each experimental tube after 21 days of incubation. Collected samples were centrifuged to remove bacterial cells, and absorbance of the supernatant was then estimated using a spectrophotometer (Helios Zeta UV-Vis, Thermo Scientific, United Kingdom) at $230 \mathrm{~nm}$ (Goldstein et al. 2004). The oligopeptide concentration in the supernatant mainly originates from keratin degradation and thus it is directly related to the amount of feather degraded. Calibration curves of absorbance and oligopeptide concentration (from 0 to $300 \mu \mathrm{g} \mathrm{x} \mathrm{mL} \mathrm{m}^{1}$ ) were obtained by using bovine serum albumin (BSA) $\left(\mathrm{R}^{2}=0.98\right.$ in both curves), which allowed us to extrapolate the absorbance to values of oligopeptide concentration.

To assure that oligopeptide measurements were due to the degradation of feathers by Bacillus licheniformis exclusively, we also prepared the following control samples: (i) tubes containing the buffer, (ii) tubes containing the buffer and the bacteria, but without the feathers, and (iii) tubes 
containing the feathers but without the bacteria. After 21 days of incubation, oligopeptide concentrations increased significantly (Repeated Measures ANOVA, effect of incubation, $\mathrm{F}=803.2, \mathrm{df}=1,360, \mathrm{P}<0.0001$ ), mainly in experimental tubes (Repeated Measures ANOVA, interaction between incubation and treatment effect, $\mathrm{F}=140.3$, df $=1,1080, \mathrm{P}<0.0001$ ). Although intermediate level of oligopeptide concentrations were detected in tubes containing feathers without bacteria that were incubated during 21 days, control tubes had significantly less oligopeptide concentration than experimental tubes (Repeated Measures ANOVA, effect of experimental treatments, $\mathrm{F}=206.2$, df $=1,1080, \mathrm{P}<0.0001$, ESM Fig 1). Thus, for subsequent analyses, as a measure of feather degradability, we conservatively used differences in oligopeptide concentration between experimental tubes containing feather and bacteria and control tubes containing feathers but not bacteria. These measures were standardized by feather weight (precision scale Mettler AB135-5/FACT, accuracy 000001g).

\section{Nest bacterial loads}

In the lab, tubes containing the bacterial samples were vigorously shaken in a vortex (Boeco V1 Plus) to remove bacteria from swabs. Afterward, we spread homogeneously $100 \mu$ l of serially diluted samples until $10^{-4}$ in Tryptic Soy Agar (TSA) and $10^{-2}$ in the others media (see below). Plates were incubated at $37{ }^{\circ} \mathrm{C}$ during 72 hours, and then the number of colonies on each plate was counted. Following the method of PeraltaSánchez et al. (2010), we used four different solid media (Scharlau Chemie S.A., Barcelona) to grow bacterial samples. We used TSA, a broadly used general medium to grow mesophilic bacteria that provide a good estimation of bacterial density (Peralta-Sánchez et al. 2010, 2012, 2018, Soler et al. 2011). We also used three differential and selective media: Kenner Fecal 
299 Agar (KF) for growing bacteria belonging to the genus Enterococcus; Vogel300 Johnsson Agar (VJ) for bacteria of the genus Staphylococcus; and Hecktoen 301 Enteric Agar (HK) for Gram-negative bacteria of the family 302 Enterobacteriaceae. Enterobacteriaceae and Staphylococcus sp. are 303 saprophytic and opportunistic bacteria (Singleton and Harper 1998, Houston et al. 1997, Cook et al. 2005) that live on skin, hair and feathers of mammals and birds (Krieg and Holt 1984). Enterococci are also opportunistic pathogens (Franz et al. 1999), although some species may also have beneficial effects (Soler et al. 2010, Martín-Vivaldi et al. 2010, RuizRodríguez et al. 2012). Bacterial load of nests for each bacterial group was then expressed as the number of colony forming units $(\mathrm{CFU})$ per $\mathrm{ml}\left(\mathrm{N}^{\circ}\right.$ colonies $\left.* 10^{\text {dilution factor }}\right) / 100 \mu \mathrm{l}$ spread).

Sample sizes and statistical analyses

313 We considered 16 species for which we collected information of feather wear for more than two nests (Table 1). For 11 of these species we successfully collected information of wear of pigmented (melanised) and unpigmented (parts of) feathers. However, because of malfunctioning of the spectrophotometer determining keratin degradation, we lost all feathers collected for this purpose during 2015. Thus, during 2016, we again collected feathers of most (11) species with information of feather wear. Nest bacterial loads were estimated for the 16 species with information of feather wear; most of the samples were in fact from the same nests where we collected the feathers to analyse their deterioration state. Nest bacterial loads were $\log 10-$ $\log 10$ transformed $(\log 10(\log 10(X+1)+1)$ before the analysis to approach normal distribution. Used Statistical models assumed Gaussian distributions and residuals were visually checked for normality. 
Interspecific variation in feather wear of melanised and non-melanised

feathers was explored in separate univariate ANOVAs with average values per nest as dependent variable and species identity as the unique independent factors. Possible differential wear between melanised and non-melanised feathers was explored with a subset of species with information for both kinds of feathers in a Repeated Measures ANOVA. Average values of feather wear per nest of melanised and non-melanised were used as repeat measures. Thus, feather pigmentation was the within independent factor and species identity as the between independent factor.

Interspecific variation in feather degradability was explored by using average nest values as the dependent variable and species identity as the only independent factor. Interspecific variation in nest bacterial loads $(\log (\log (\mathrm{X}))$ transformed data) were explored in a MANOVA, with bacterial loads of mesophilic bacteria, enterobacteria, staphylococci and enterococci as multiple dependent variables and species identity as the independent factor.

The association between feather wear and nest bacterial loads was explored in General Linear Models (GLM) that did include species identity as additional independent factor to those reflecting nest bacterial load (i.e., the four bacterial groups). The expected associations were explored separately for melanised and non-melanised feathers, but also for the subset of species with information on degradation of melanised and non-melanised feathers in a repeated measures design. In this case, values for pigmented and unpigmented feathers were included as dependent variables in a Repeated Measures ANOVA (i.e. pigmentation as repeated measure), and bacterial loads of mesophilic bacteria, staphylococci, enterococci and enterobacteria as independent covariables. This model also included species identity as an additional independent factor. For all these models trying to 
explore the expected association between bacterial loads and feather wear, we adopted a backward stepwise procedure for model selection where factors with the largest $p$-values were removed one by one up to a p-value lower than 0.1. Final reduced models coincide with best models from AIC criteria (results not shown).

To explore the associations between feather degradability and feather wear, and between feather degradability and nest bacterial loads, we performed regression analyses. Since feather degradability and feather degradation were estimated from samples collected in different nests, but bacterial environment were estimated from the nests where feathers for estimating degradation were collected, we used average species values of feather degradability, but nest values for bacterial environment and feather wear. The analyses including information of feather degradability did not include species identity as independent factor because no within species variance exists in feather degradability.

The effects of age (fledging $v s$ adults) (independent factor) on feather degradability (dependent variables) were explored in General Linear Models that also included species identity as additional independent factor. Feather wear was estimated for several nestling within the same nest and, thus, the effects of age on this variable were analysed in General Linear Mixed Models that included species identity as additional independent fixed factor and nest identity nested within the interaction between species identity and age as the random factor. We estimated the interaction between age and species identity in separate models that also included main affects, while main effects were estimated in models that did not include interactions.

Finally, expected association between feather deterioration or feather susceptibility to degradation and nest bacterial loads were also explored in weighted phylogenetic linear models (wPGLS) with average per species 
382

383

384

385

386

387

388

389

390

391

392

393

394

395

396

397

398

399

400

401

402

403

404

405

406

407

408

values. As far as we know, available methodologies to consider within species variance into the PGLS models is restricted to one of the predictor variables (Garamszegi and Møller 2010, Garamszegi 2014) and, thus, degrees of freedom were reduced to those reflecting number of species. Briefly, we used consensus phylogenetic trees from 1000 downloaded trees from birdtree.org (Jetz et al. 2012) and used wPGLS following recommendations by Garamszegi (2014) in R (version 3.6.1) with libraries ape (Paradis and Schliep 2018) and nlme (Pinheiro et al. 2019).

All statistical tests were performed in Statistica V13 (Dell-Inc 2015).

\section{Results}

\section{Feather wear; interspecific comparisons}

We found interspecific differences in wear of secondary covert feathers of nestling birds, both for melanised $(\mathrm{F}=7.24, \mathrm{df}=14,146, \mathrm{P}<0.0001)$ and non-melanised feathers $(\mathrm{F}=11.50, \mathrm{df}=10,132, \mathrm{P}<0.0001)$. Blue tits (Cyanistes caeruleus) and black wheatears (Oenanthe leucura) were the species with most damaged melanised feathers, while those of pied flycatchers (Ficedula hypoleuca) and magpies (Pica pica) were the least damaged (Fig. 1A). When considering non-melanised feathers, the blue tit had again the highest feathers wear, while non-melanised feathers of hoopoes (Upupa epops) were by far those least damaged (Fig 1A). Finally, degradation of non-melanised feathers (mean $(\mathrm{SE})=1.57(0.04))$ did not differ significantly from that of melanised feathers (mean $(\mathrm{SE})=1.51(0.04)$; Repeated measures, pigmentation effects: $\mathrm{F}=1.15, \mathrm{df}=1,128, \mathrm{P}=0.28$ ). However, in some species the melanised feathers were more degraded that the unpigmented ones, while in some other species the tendency was the 
409

410

411

412

413

414

415

416

417

418

419

420

421

422

423

424

425

426

427

428

429

430

431

432

433

434

435

opposite resulting in a statistically significant interaction between feather pigmentation and species identity (Fig 1A; Repeated measures, $\mathrm{F}=7.15$, df $=9,128, \mathrm{P}<0.0001)$. These differences are mainly due to hoopoes and pied flycatchers (Fig 1A).

\section{Feather degradability; interspecific comparisons}

We found interspecific differences in feather degradability $(\mathrm{F}=5.26$, df $=$ $11,107, \mathrm{P}<0.0001$ ), even after controlling for the positive influence of feather mass used $($ Beta $(\mathrm{SE})=0.83(0.18), \mathrm{F}=21.78, \mathrm{df}=1,107), \mathrm{P}<$ 0.0001). Covert feathers of nestlings of little owls (Athene noctua), pied flycatchers, great tits (Parus major), hoopoes and blue tits, were the most easily degraded, while those of choughs (Pyrrhocorax pyrrhocorax), jackdaws (Corvus monedula) and magpies (Pica pica) were the most resistant to bacterial degradation (Fig. 1B).

\section{$\underline{\text { Nest bacterial loads; interspecific comparisons }}$}

Estimated nest bacterial loads of different groups of bacteria covaried with each other $(\mathrm{R}($ Max-Min $)=0.65-0.46, \mathrm{~N}=161, \mathrm{P}<0.0001)$. We detected a large interspecific variation (MANOVA, Wilks' $\lambda=0.26, \mathrm{~F}=3.80, \mathrm{df}=60$, 556.5, $\mathrm{P}<0.0001$; univariate results: $\mathrm{F}>3.018, \mathrm{df}=15,145, \mathrm{P}<0.0003$ ) that depended on the considered bacterial group (Fig. 1C). However, independently of the bacterial group considered, nests of some species consistently harboured the lowest or the largest densities. For example, little owls, jackdaws and hoopoes were those with higher mesophilic bacterial loads, while nests of swallows (Hirundo rustica), choughs, and magpies harboured the lowest densities of this bacterial group. When considering Enterobacteriaceae and Staphylococcus, nests of hoopoes were those with 
436 the highest density, while those of swallows harboured the lowest densities

437 of these bacterial groups. Finally, when considering Enterococcus, nests of rollers (Coracias garrulus) and of hoopoes were those with the highest bacterial density, and nests of swallows again showed the lowest densities (Fig. 1C).

Feather wear and nest bacterial loads

443

Nest bacterial loads predicted wear of nestling feathers, (mainly those melanised). After controlling for the effect of species identity, the density of enterobacteria resulted positively associated with melanised feathers wear (Table 2, Fig. 2). Interestingly, in final-reduced models, density of mesophilic bacteria resulted negatively associated with melanised feather wear (Table 2, Fig. 2). When considering non-melanised feathers, no bacterial counts explained a significant proportion of variance of feather wear $(\mathrm{F}<2.16, \mathrm{df}=1,124, \mathrm{P}>0.14)$, even after correcting for the effect of species identity $(\mathrm{F}=10.15, \mathrm{df}=10,124, \mathrm{P}<0.0001)$.

Differences in feather wear between non-melanised and melanised feathers (i.e. only species with these two kinds of feathers considered) depend on nest bacterial environment (enterobacteria (negatively, Fig. 2) and mesophilic bacterial loads (positively, Fig. 2)). Moreover, after controlling for nest bacterial environment, within-nest differences in degradation of nonmelanised minus melanised feathers resulted significantly different from zero; non-melanised were more degraded than melanised feathers (see within nest repeated measures in Table 2). That was the case after correcting for the effect of species identity (Table 2) 
463 Average degradability of feathers of different species tended to be positively 464 related to wear of non-melanised feathers $(\operatorname{Beta}(\mathrm{SE})=0.16(0.09), \mathrm{F}=3.27$, $465 \mathrm{df}=1,126, \mathrm{P}=0.073)$, but not to that of melanised $(\operatorname{Beta}(\mathrm{SE})=0.01(0.08)$, $466 \mathrm{~F}=0.01$, df $=1,138, \mathrm{P}=0.958)$. Moreover, in the final model, feather 467 degradability resulted negatively related to staphylococci bacterial loads and

468

469

470

471

472

473

474

475

476

477

478

479

480

481

482

483

484

485

486

487

488

489 tended to be positively related to mesophilic and enterobacteria loads of sampled nests (see feather degradability in Table 2).

When considering both factors in the same models, feather degradability and nest bacterial environment explained feather wear. Feather degradability did not explain significant proportion of variance of wear index of melanised feathers $(\operatorname{Beta}(\mathrm{SE})=-0.01(0.08), \mathrm{F}=0.02, \mathrm{df}=130, \mathrm{P}=0.895)$, but bacterial environment did after controlling for species identity as showed in Table 2 (see wear of melanised feathers). On the other hand, wear of nonmelanised feathers was positively associated with feather degradability and negatively, but not significantly, with staphylococci and enterococci bacterial loads of the nests (see wear of melanised feathers and feather degradability in Table 2).

All statistically significant associations disappeared when considering mean values per species of feather degradation, feather degradability and nest bacterial environment, and controlled for phylogenetic association among them (PGLS, P > 0.07,ESM, Table 1).

\section{Wear and degradability of adults and nestling feathers}

For the seven species with information on feather wear, interspecific variation of adults and nestlings followed a similar pattern (see the effect of age in Table 3). Only in hoopoes, feather wear of nestlings was higher than that detected in adult hoopoes (Fig 3A). Moreover, feathers of adult 
490

491

492

493

494

495

496

497

498

499

500

501

502

503

504

505

506

507

508

509

510

511

512

513

514

515

516

517

individuals were more resistant to bacterial degradation than those of nestlings. However, rank positions of feather degradability of adults and nestlings coincided except for hoopoes (Fig. 3B), which are the responsible of the significant interaction between species and age (Table 3).

\section{Discussion}

We here estimated feather wear and degradability in fledglings and nest bacterial loads in nests of 16 species of Palaearctic birds, and detected statistically significant interspecific variation for all considered variables. On average, non-melanised feathers were more deteriorated than melanised feathers, but it was only detected when comparing feathers of nestlings within the same nests, and after controlling for bacterial environment. Moreover, our results suggest that the feather deterioration state was explained by feather degradability (only for non-melanised feathers) and nest bacterial environment. Feather degradability was also explained by nest bacterial environment, suggesting that the nest microbiome determines the integrity of fledgling feathers as well as their strength to resist bacterial degradation. These last results were however not controlled for phylogenetic effects. Below we discuss and offer several possible explanations for the sign of the detected associations.

Consistent with previous papers claiming that non-melanised feathers are more easily degraded by bacterial activity than melanised feathers (Goldstein et al. 2004, Gunderson et al. 2008, Ruiz-de-Castañeda et al. 2012), we found that non-melanised feathers of fledglings were more deteriorated than melanised feathers of the same individual. Feather deterioration was estimated for wing cover feathers and, thus, we assumed that melanised and non-melanised parts of feathers should have experienced a similar risk of deterioration. Moreover, the pigmentation effect on feather 
518 deterioration was only detected when comparing melanised and non519 melanised feathers within the same nest (i.e. repeated measures). These

520

521

522

523

524

525

526

527

528

529

530

531

532

533

534

535

536

537

538

539

540

541

542

543

544

545 results suggest that the detected differences are due to differential effects of nest bacterial environment on melanised and non-melanised feathers, which might be explained by melanin conferring resistance (Bonser 1995) to feathers or/and different feather microstructure, which would confer different resistance to melanised and non-melanised part of feathers (2012, Ruiz-Rodríguez et al. 2015). This general pattern of non-melanised feathers being more deteriorated does not occur in all studied species, with hoopoes showing the opposite patterns, and some other species showing no apparent differences. We did not consider the possibility that different species varied in the quality and quantity of pigments in analysed feathers or in the microstructure of feathers of different colouration (Schreiber et al. 2006, Ruiz-de-Castañeda et al. 2012), which might partially explain interspecific differences in the effect of feather pigmentation. Future work directed to explore interspecific differences in pigmentation and microstructure of feathers would clarify the importance of such characters in explaining detected interspecific differences in feather wear.

The most robust result is the detected interspecific differences in all considered variables. Interspecific differences in nest bacterial environment estimated as eggshell bacterial loads were first detected by Peralta-Sánchez et al. (2012), whom also demonstrated associations with life history characteristics and hatching success (Peralta-Sánchez et al. 2018). Here, we directly sampled nest materials and for the first time confirm interspecific variation in nest bacterial environment that should affect probability of bacterial contamination of eggs, nestlings and adults. Moreover, we also found significant interspecific variation in feathers' susceptibility to bacterial degradation, which was first suggested by Burtt et al. (2011) in 
association with interspecific differences among feathers' pigmentation of 13 parrot species. Interestingly, these authors suggested that interspecific differences in feather degradability should be explained by the risk of feather degradation typically experienced by each species. If this was the case, interspecific differences in degradation state of feathers collected from the same body parts (i.e. wing feathers) and at similar stage (similar nestling developmental stage) should be close to zero. However, our results did not fit this prediction, but pointed out interspecific differences in feather susceptibility to degradation. Our results, therefore, suggest that feather resistance do not completely adapt to risk of bacterial degradation, and that some other factors will play a role.

Interspecific differences in factors affecting feather wear could explain the detected differences in deterioration of fledgling feathers. We characterized interspecific differences in feather degradability and in nest bacterial environment to explore whether these characteristics were responsible of the wear variability of fledgling feathers, and it resulted associated with bacterial load of nests where sampled fledglings grew. However, the sign of the association depended of feather pigmentation and of the bacterial group considered. Negative associations between bacterial loads of nests and feather deterioration can be explained in several ways. First, feathers of species developing in nests with higher bacterial densities could be more resistant to bacterial degradation. Partly in accordance with this a posteriori explanation, we found that feather degradability was lower in species with a high density of staphylococci in their nests. However, the association turned to be positive when considering mesophilic bacteria or enterobacteria, which suggest that the possible influences of nest bacterial environment on the evolution of feather resistance to bacterial deterioration would depend on the bacterial group considered and of characteristics of the 
574 bacterial community in relation to the risk of feather deterioration by

575 microorganisms. This speculative inference links the first to the second 576 possibility explaining the detected negative association between bacterial

577 loads of nests and feather wear index. This second explanation posits that

578 characteristics of the bacterial community, or that some bacteria in avian 579 nests, could protect nestling feathers from feather-degrading 580 microorganisms. If that was the case, feathers of species with protecting 581 bacteria in their nests should be more susceptible to bacterial degradation. 582 On the one hand, nest environments with higher bacterial densities might harbour keratinolytic bacteria in lower proportion than those with lower bacterial density. This possibility is however unlikely since mesophilic and keratinolytic bacterial densities are positively correlated, at least in starling feathers (Ruiz-Rodríguez et al. 2015). It might also be possible that bacteria producing antibiotics against keratinolitic ones occur at higher relative density in nests with higher bacterial densities. Bacterial antimicrobials function by reducing competition for space and resources against other bacterial strains (Ji et al. 1997, Riley and Wertz 2002), and bacterial density is one of the factors known to enhance antimicrobial production (Riley and Wertz 2002). Thus, it is possible that high-density bacterial communities also produce high level of antimicrobials against keratinolytic bacteria able to colonize feather tissues, resulting in lower levels of feather degradation. However, we did not quantify the density of keratinolytic bacteria in nest environments nor in nestling feathers, which is necessary to test and discuss this possibility.

Another possibility that could explain the negative association between nest-bacterial density and wear of unpigmented feathers is that this part of nestling feathers function honestly reflecting (i.e., signalling) individual abilities of nestlings to maintain plumage integrity during the last 
602

603

604

605

606

607

608

609

610

611

612

613

614

615

616

617

618

619

620

621

622

623

624

625

626

627

628

629

days of the nestling stage (Morales et al. 2019). Reliability of signals partly depends on costs associated with their production, showiness and/or maintenance (Maynard-Smith and Harper 2003), and fledglings showing non-degraded plumage, or plumage of a particular coloration, might signal its phenotypic quality to conspecifics (López-Idiáquez et al. 2018). Following the handicap principle (Zahavi and Zahavi 1997), individuals will show their ability to resist bacterial infection more honestly if they use traits that, as it occurs for unpigmented feathers, are more easily infected but are revealed with no or reduced sign of bacterial infection. The role of bacteria in the evolution of feather characteristics that honestly signal phenotypic quality of holders has been previously demonstrated in adult males of the spotless starling (Sturnus unicolor), which wear delicate, long sexual feathers that are easily degraded by bacteria and that harbour bacteria at a higher density than non-sexual feathers (Ruiz-Rodríguez et al. 2015). Only males with a higher capacity to prevent feather wear by bacteria will show non-deteriorated feathers. Similarly, only good quality fledglings would show non-degraded white patches on their feathers. Signalling roles of fledgling plumage in different scenarios of social interaction have been recently proposed to explain juvenile plumage patterns (Moreno and Soler 2011, Ligon and Hill 2013, Fargallo et al. 2014, Romano et al. 2016, Galván 2017, Morales et al. 2019). Our results show that feather degradability explains feather wear, but mainly that of non-melanised feathers, which is in accordance with the proposed scenario. However, melanised feathers were less deteriorated than non-melanised feathers in some, but not all species, which is contrary to the proposed scenario. Future work should concentrate on exploring this hypothesis intra- and interspecifically.

Detected associations that included feather degradability should be considered cautiously since they are not controlled by species identity. The 
630

impossibility of controlling these analyses for species identity was because information on feather degradability, and nest bacterial loads or feather wear, were not available for the same individuals and nests, which impede the estimation of intraspecific covariance matrices. Moreover, the effects disappeared when using mean values per species in phylogenetically controlled analyses. These analyses however included only 11 species, which implies a reduced statistical power that prevent to reach strong conclusions. Thus, further investigations estimating feather wear, feather degradability and nest bacterial density in the same individuals and nests, or increasing the number of species with this kind of information, are necessary to reach firmer conclusions.

Summarising, we found clear interspecific differences in the deterioration state of fledgling feathers that tended to parallel interspecific differences in feather resistance to bacterial degradation, and in nest bacterial environment, which suggest a role of bacteria in determining such interspecific variation. The sings of the association between nest bacterial loads and feather deterioration depend on the bacterial group considered so the different possible explanations offered should be considered as preliminary and further tested both at the intra- and interspecific levels.

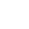

\section{Acknowledgments}

We thank Estefanía López Hernández and Pilar Fuentetaja Casado for assistance in laboratory work and Natalia Juárez García-Pelayo for assistance in fieldwork. We benefited from comments by two anonymous referees that improved the quality of the manuscritp. This work was supported by the currently named Ministerio de Ciencia, Innovación y Universidades and European (FEDER) funds (CGL2013-48193-C3-1-P, CGL2013-48193-C3-2-P, CGL2013-48193-C3-3-P, CGL2017-83103-P). 
658

659

660

661

662

663

664

665

666

667

668

669

670

671

672

673

674

675

676

677

678

679

680

681

682

683

684

685

686

687

688

689

690

691

692

MAG and SDL were financed by predoctoral contracts (BES-2014-068661, BES-2014-069116) from the Spanish Ministerio de Economía y Competitividad. The authorization for carrying out the experimental work on animals in the field was granted by the Dirección General de Gestión del Medio Natural of the Consejería de Medio Ambiente of Junta de Andalucía (Guadix) and by the Dirección General del Medio Natural of Junta de Castilla y León (Valsaín).

\section{Author contributions}

Conceived and designed work: JJS, MMV, JM, MMB and MRR. Performed the field and laboratory work: MAG, SGB, SDL, JJS, MMV and MRR. Analysed the data: MAG and JJS. Contributed reagents/materials/analysis tools: MAG, MMB, SDL and MRR. JJS an MAG wrote the manuscript with substantial contribution from all authors.

\footnotetext{
References

Andersson, M. 1994. Sexual selection, Princeton, Princeton University Press.

Azcárate-García, M., Ruiz-Rodríguez, M., Díaz-Lora, S., Ruiz-Castellano, C. and José Soler, J. 2019. Experimentally broken faecal sacs affect nest bacterial environment, development and survival of spotless starling nestlings. - J. Avian Biol. 50: UNSP e02044.

Bonser, R. H. C. 1995. Melanin and the abrasion resistance of feathers. - Condor 97: 590591.

Burtt, E. H. 1979. Tips on wings and other things. In: Burtt, E. H. (ed.) The Behavioural Significance of Color. Garland Publishing Inc., New York, pp. 75-100.

Burtt, E. H. 2009. A future with feather-degrading bacteria. - J. Avian Biol. 40: 349-351.

Burtt, E. H. and Ichida, J. M. 2004. Gloger's rule, feather-degradlng bacteria, and color variation among song sparrows. - Condor 106: 681-686.

Burtt, E. H., Schroeder, M. R., Smith, L. A., Sroka, J. E. and Mcgraw, K. J. 2011. Colourful parrot feathers resist bacterial degradation. - Biol. Lett. 7: 214-216.

Callan, L. M., La Sorte, F. A., Martin, T. E. and Rohwer, V. G. 2019. Higher Nest Predation Favors Rapid Fledging at the Cost of Plumage Quality in Nestling Birds. - Am. Nat. 193: 717-724.
} 
Cook, M. I., Beissinger, S. R., Toranzos, G. A. and Arendt, W. J. 2005. Incubation reduces microbial growth on eggshells and the opportunity for trans-shell infection. - Ecol. Lett. 8: 532-537.

Cristol, D. A., Armstrong, J. L., Whitaker, J. M. and Forsyth, M. H. 2005. Featherdegrading bacteria do not affect feathers on captive birds. - Auk 122: 222-230.

Delhey, K. 2017. Gloger's rule. - Current Biology 27: R689-R691.

Dell-Inc. 2015. STATISTICA (data analysis software system), version 13, software.dell.com.

Fargallo, J. A., Velando, A., Lopez-Rull, I., Ganan, N., Lifshitz, N., Wakamatsu, K. and Torres, R. 2014. Sex-specific phenotypic integration: endocrine profiles, coloration, and behavior in fledgling boobies. - Behav. Ecol. 25: 76-87.

Francis, C. M. and Wood, D. S. 1989. Effects of age and wear on wing length of wood warblers. - Journal of Field Ornithology 60: 495-503.

Franz, C. M. a. P., Holzapfel, W. H. and Stiles, M. E. 1999. Enterococci at the crossroads of food safety? - International Journal of Food Microbiology 47: 1-24.

Galván, I. 2017. Condition-dependence of pheomelanin-based coloration in nuthatches Sitta europaea suggests a detoxifying function: implications for the evolution of juvenile plumage patterns. - Sci. Rep. 7: 9138.

Garamszegi, L. 2014. Uncertainties Due to Within-Species Variation in Comparative Studies: Measurement Errors and Statistical Weights. pp. 157-199.

Garamszegi, L. Z. and Møller, A. P. 2010. Effects of sample size and intraspecific variation in phylogenetic comparative studies: a meta-analytic review. - Biol. Rev. 4: 797-805.

Goldstein, G., Flory, K. R., Browne, B. A., Majid, S., Ichida, J. M. and Burtt, E. H. 2004. Bacterial degradation of black and white feathers. - Auk 121: 656-659.

González-Braojos, S., Sanz, J. J. and Moreno, J. 2017. Decline of a montane Mediterranean pied flycatcher Ficedula hypoleuca population in relation to climate. - J. Avian Biol. 48: 1383-1393.

Gunderson, A. R. 2008. Feather degrading bacteria: a new frontier in avian and hostparasite research? - Auk 125: 972-979.

Gunderson, A. R., Frame, A. M., Swaddle, J. P. and Forsyth, M. H. 2008. Resistance of melanized feathers to bacterial degradation: is it really so black and white? - J. Avian Biol. 39: 539-545.

Hanson, T. 2011. Feathers: the evolution of a natural miracle, New York, Basic Books.

Houston, C. S., Saunders, J. R. and Crawford, R. D. 1997. Aerobic bacterial flora of addled raptor eggs in Saskatchewan. - Journal of Wildlife Diseases 33: 328-331.

Jacob, S., Salle, L., Zinger, L., Chaine, A. S., Ducamp, C., Boutault, L., Russell, A. F. and Heeb, P. 2018. Chemical regulation of body feather microbiota in a wild bird. - Mol. Ecol. 27: 1727-1738.

Javůrková, V. G., Kreisinger, J., Procházka, P., Požgayová, M., Ševčíková, K., Brlík, V., Adamík, P., Heneberg, P. and Porkert, J. 2019. Unveiled feather microcosm: feather microbiota of passerine birds is closely associated with host species identity and bacteriocin-producing bacteria. - ISME J.

Jetz, W., Thomas, G. H., Joy, J. B., Hartmann, K. and Mooers, A. O. 2012. The global diversity of birds in space and time. - Nature 491: 444-448.

Ji, G., Beavis, R. and Novick, R. P. 1997. Bacterial interference caused by autoinducing peptide variants. - Science 276: 2027-2030.

Jovani, R. and Rohwer, S. 2017. Fault bars in bird feathers: mechanisms, and ecological and evolutionary causes and consequences. - Biol. Rev. 92: 1113-1127. 
Kent, C. M. and Burtt, E. H. 2016. Feather-degrading bacilli in the plumage of wild birds: Prevalence and relation to feather wear. - Auk 133: 583-592.

Kose, M. and Møller, A. P. 1999. Sexual selection, feather breakage and parasites: the importance of white spots in the tail of the barn swallow (Hirundo rustica). Behav. Ecol. Sociobiol. 45: 430-436.

Krieg, N. R. and Holt, J. G. 1984. Bergey's manual of systematic bacteriology, Baltimore, Maryland, Williams \& Wilkins.

Leclaire, S., Pierret, P., Chatelain, M. and Gasparini, J. 2014. Feather bacterial load affects plumage condition, iridescent color, and investment in preening in pigeons. - Behav. Ecol. 25: 1192-1198.

Ligon, R. A. and Hill, G. E. 2013. Is the juvenal plumage of altricial songbirds an honest signal of age? Evidence from a comparative study of thrushes (Passeriformes: Turdidae). - Journal of Zoological Systematics and Evolutionary Research 51: 6471.

López-Idiáquez, D., Fargallo, J. A., López-Rull, I. and Martínez-Padilla, J. 2018. Plumage coloration and personality in early life: sexual differences in signalling. - Ibis 0.

Martín-Vivaldi, M., Peña, A., Peralta-Sánchez, J. M., Sánchez, L., Ananou, S., RuizRodríguez, M. and Soler, J. J. 2010. Antimicrobial chemicals in hoopoe preen secretions are produced by symbiotic bacteria. - Proc. R. Soc. Lond., B, Biol. Sci. 277: 123-130.

Martín-Vivaldi, M., Ruiz-Rodríguez, M., Mendez, M. and Soler, J. J. 2006. Relative importance of factors affecting nestling immune response differs between junior and senior nestlings within broods of hoopoes Upupa epops. - J. Avian Biol. 37: 467-476.

Maynard-Smith, J. and Harper, D. 2003. Animal Signals, Oxford, Oxford University Press.

Minias, P., Wlodarczyk, R., Surmacki, A. and Iciek, T. 2015. Silver spoon effects on plumage quality in a passerine bird. - R Soc Open Sci 2: 140459.

Møller, A. P., Barbosa, A., Cuervo, J. J., De Lope, F., Merino, S. and Saino, N. 1998. Sexual selection and tail streamers in the barn swallow. - Proc. R. Soc. Lond., B, Biol. Sci. 265: 409-414.

Møller, A. P., Peralta-Sánchez, J. M., Nielsen, J. T., López-Hernández, E. and Soler, J. J. 2012. Goshawk prey have more bacteria than non-prey. - J. Anim. Ecol. 81: 403410.

Morales, J., Cuervo, J. J., Moreno, J. and Soler, J. J. 2019. Juvenile plumage whiteness is associated with the evolution of clutch size in passerines. - Behav. Ecol.

Moreno, J. and Soler, J. J. 2011. Sources of distinctness of juvenile plumage in Western Palearctic passerines. - Biol. J. Linn. Soc. 102: 440-454.

Paradis, E. and Schliep, K. 2018. ape 5.0: an environment for modern phylogenetics and evolutionary analyses in R. - Bioinformatics (Oxford, England) 35.

Peralta-Sánchez, J. M., Martín-Platero, A. M., Wegener-Parfrey, L., Martínez-Bueno, M., Rodríguez-Ruano, S., Navas-Molina, J. A., Vázquez-Baeza, Y., Martín-Gálvez, D., Martín-Vivaldi, M., Ibáñez-Álamo, J. D., Knight, R. and Soler, J. J. 2018. Bacterial density rather than diversity correlates with hatching success across different avian species. - FEMS Microbiology Ecology 94: fiy022-fiy022.

Peralta-Sánchez, J. M., Martín-Vivaldi, M., Martín-Platero, A. M., Martínez-Bueno, M., Oñate, M., Ruiz-Rodríguez, M. and Soler, J. J. 2012. Avian life history traits influence eggshell bacterial loads: a comparative analysis. - Ibis 154: 725-737. 
Peralta-Sánchez, J. M., Møller, A. P., Martín-Platero, A. M. and Soler, J. J. 2010. Number and colour composition of nest lining feathers predict eggshell bacterial community in barn swallow nests: an experimental study. - Funct. Ecol. 24: 426433.

Pinheiro, J., Bates, D., Debroy, S., Sarkar, D. and Team, R. C. 2019. \{nlme\}: Linear and Nonlinear Mixed Effects Models. R package version 3.1-141, https://CRAN.Rproject.org/package $=$ nlme.

Rayner, J. M. V. 1988. Form and function in avian flight. In: Johnston, R. F. (ed.) Current Ornithology. Springer US, Boston, MA, pp. 1-66.

Riley, M. A. and Wertz, J. E. 2002. Bacteriocines: evolution, ecology, and application. Annual Review of Microbiology 56: 117-137.

Romano, A., Bazzi, G., Caprioli, M., Corti, M., Costanzo, A., Rubolini, D. and Saino, N. 2016. Nestling sex and plumage color predict food allocation by barn swallow parents. - Behav. Ecol. 27: 1198-1205.

Roulin, A. 2016. Condition-dependence, pleiotropy and the handicap principle of sexual selection in melanin-based colouration. - Biol. Rev. 91: 328-348.

Ruiz-Castellano, C., Ruiz-Rodríguez, M., Tomás, G. and Soler, J. J. 2019. Antimicrobial activity of nest-lining feathers is enhanced by breeding activity in avian nests. FEMS Microbiology Ecology 95.

Ruiz-Castellano, C., Tomás, G., Ruiz-Rodríguez, M., Martín-Gálvez, D. and Soler, J. J. 2016. Nest material shapes eggs bacterial environment. - PLoS ONE 11: $\mathrm{e} 0148894$.

Ruiz-Castellano, C., Tomás, G., Ruiz-Rodríguez, M. and Soler, J. J. 2017. Nest materials, bacterial load, and fitness of nestling birds. - Submitted.

Ruiz-De-Castaneda, R., Burtt, E. H., Gonzalez-Braojos, S. and Moreno, J. 2015. Bacterial degradability of white patches on primary feathers is associated with breeding date and parental effort in a migratory bird. - Ibis 157: 871-876.

Ruiz-De-Castañeda, R., Burtt Jr, E., González--Braojos, S. and Moreno, J. 2012. Bacterial degradability of an intrafeather unmelanized ornament: a role for featherdegrading bacteria in sexual selection? - Biol. J. Linn. Soc. 105: 409-419.

Ruiz-Rodríguez, M., Møller, A. P., Mousseau, T. A. and Soler, J. J. 2016. Defenses against keratinolytic bacteria in birds living in radioactively contaminated areas. - The Science of Nature 103: 1-8.

Ruiz-Rodríguez, M., Tomás, G., Martín-Gálvez, D., Ruiz-Castellano, C. and Soler, J. J. 2015. Bacteria and the evolution of honest signals. The case of ornamental throat feathers in spotless starlings. - Funct. Ecol. 29: 701-709.

Ruiz-Rodríguez, M., Valdivia, E., Martín-Vivaldi, M., Martín-Platero, A. M., MartínezBueno, M., Méndez, M., Peralta-Sánchez, J. M. and Soler, J. J. 2012. Antimicrobial activity and genetic profile of enteroccoci isolated from hoopoes uropygial gland. - PLoS ONE 7: e41843.

Ruiz-Rodríguez, M., Valdivia, E., Soler, J. J., Martin-Vivaldi, M., Martin-Platero, A. M. and Martinez-Bueno, M. 2009. Symbiotic bacteria living in the hoopoe's uropygial gland prevent feather degradation. - J. Exp. Biol. 212: 3621-3626.

Schreiber, R. W., Schreiber, E. A., Peele, A. M. and H., B. J. E. 2006. Pattern of damage to albino great frigatebird flight feathers supports hypothesis of abrasion by airborne particles. - The Condor 108: 736-741, 6.

Senar, J. 2006. Color displays as intrasexual signal of agression and dominance In: Hill, G. E. and Mcgraw, K. J. (eds.) Bird coloration: Function and evolution. Harvard University Press, Cambridge, Massachusetts, pp. 87-136. 
Shawkey, M. D., Pillai, S. R. and Hill, G. E. 2009. Do feather-degrading bacteria affect sexually selected plumage color? - Naturwissenschaften 96: 123-128.

Shawkey, M. D., Pillai, S. R., Hill, G. E., Siefferman, L. M. and Roberts, S. R. 2007. Bacteria as an agent for change in structural plumage color: Correlational and experimental evidence. - Am. Nat. 169: S112-S121.

Singleton, D. R. and Harper, R. G. 1998. Bacteria in old house wren nests. - J. Field. Ornithol 69: 71-74.

Soler, J. J. and Avilés, J. M. 2010. Sibling competition and conspicuousness of nestling gapes in altricial birds: a comparative study. - PLoS ONE 5: e10509.

Soler, J. J., Martín-Vivaldi, M., Peralta-Sánchez, J. M. and Ruiz-Rodríguez, M. 2010. Antibiotic-producing bacteria as a possible defence of birds against pathogenic microorganisms. - Open Ornithology Journal 3: 93-100.

Soler, J. J., Peralta-Sánchez, J. M., Flensted-Jensen, E., Martín-Platero, A. M. and Møller, A. P. 2011. Innate humoural immunity is related to eggshell bacterial load of European birds: a comparative analysis. - Naturwissenschaften 98: 807-813.

Soler, J. J., Ruiz-Rodríguez, M., Martín-Vivaldi, M., Peralta-Sánchez, J. M., RuizCastellano, C. and Tomas, G. 2015. Laying date, incubation and egg breakage as determinants of bacterial load on bird eggshells: Experimental evidence. Oecologia 179: 63-64.

Stettenheim, P. R. 2000. The integumentary morphology of modern birds - An Overview. - Amer. Zool. 40: 461-477.

Swaddle, J. P., Witter, M. S., Cuthill, I. C., Budden, A. and Mccowen, P. 1996. Plumage condition affects flight performance in common starlings: Implications for developmental homeostasis, abrasion and moult. - J. Avian Biol. 27: 103-111.

Zahavi, A. and Zahavi, A. 1997. The handicap principle; a missing piece of Darwin's puzzle, Oxford, Oxford University Press. 
867 Table 1: Sample sizes to estimate degradation of pigmented and 868 unpigmented feathers, feathers degradability and nest bacterial loads of 869 different species.

870

\begin{tabular}{|c|c|c|c|}
\hline $\mathrm{N}=\mathrm{Nes}$ & athers) & $\mathrm{N}=$ Nests & $\mathrm{N}=$ Nests \\
\hline \multicolumn{2}{|c|}{ Feather wear } & Feather & Bacterial \\
\hline Melanised & $\begin{array}{l}\text { Non- } \\
\text { elanise }\end{array}$ & Degradability & loads \\
\hline
\end{tabular}

\begin{tabular}{lcccc}
\hline Athene noctua & 13 & 13 & 9 & 13 \\
Clamator glandarius & 9 & 9 & 15 & 9 \\
Coracias garrulus & 6 & 6 & & 6 \\
Corvus monedula & 6 & & 6 & 6 \\
Cyanistes caeruleus & 5 & 5 & 10 & 5 \\
Ficedula hypoleuca & 23 & 25 & 10 & 24 \\
Hirundo rustica & 3 & 0 & & 3 \\
Oenanthe leucura & 3 & 0 & & 3 \\
Otus scops & 12 & 12 & 5 & 11 \\
Parus major & 19 & 18 & 18 & 17 \\
Passer domesticus & 8 & 8 & & 8 \\
Petronia petronia & & 3 & 4 & 3 \\
Pica pica & 17 & 17 & 15 & 17 \\
Pyrrhocorax pyrrhocorax & 5 & & 11 & 5 \\
Sturnus unicolor & 5 & & 9 & 5 \\
Upupa epops & 26 & 26 & 8 & 26 \\
\hline
\end{tabular}


872 Table 2: Results from GLM models exploring the effects of nest bacterial 873 environment (estimated as density of mesophilic bacteria, enterobacteria, 874 staphylococci and enterococci) on (1) wear of melanised feathers, on (2) 875 differences in wear of melanised and non-melanised of the same individual 876 (repeated measures), after controlling for the effect of species identity. The 877 effects of nest bacterial environment on feather degradability (average 878 species values) were also explored in (3) GLM models. Finally, Results 879 from GLM models exploring the effect of both bacterial environment and 880 feather degradability (average species values) on wear of melanised 881 feathers are also showed (4). We show statistics associated with full and 882 final models (i.e., after a backward procedure, eliminating one by one the 883 independent variable with the larger p-value up to 0.1. Variables associated 884 with p-values smaller than 0.1 are showed in bold fonts to facilitated 885 interpretation to readers. 


\begin{tabular}{|c|c|c|c|c|c|c|c|c|}
\hline & \multirow{2}{*}{\multicolumn{4}{|c|}{ Full models }} & \multirow{2}{*}{\multicolumn{4}{|c|}{ Final models }} \\
\hline & & & & & & & & \\
\hline & $\operatorname{Beta}(\mathrm{SE})$ & $\bar{F}$ & $\overline{\mathrm{df}}$ & $\mathrm{P}$ & $\operatorname{Beta}(\mathrm{SE})$ & $\mathrm{F}$ & df & $\mathrm{P}$ \\
\hline \multicolumn{9}{|c|}{ Wear of melanised feathers (1) } \\
\hline Mesophilic bacteria & $-0.179(0.098)$ & 3.31 & 1,137 & 0.07 & $-0.238(0.092)$ & 6.75 & 1,139 & 0.010 \\
\hline Enterobacteria & $0.206(0.099)$ & 4.30 & 1,137 & 0.04 & $0.157(0.095)$ & 2.75 & 1,139 & 0.099 \\
\hline Staphylococci & $-0.094(0.095)$ & 0.97 & 1,137 & 0.33 & & & & \\
\hline Enterococci & $-0.132(0.108)$ & 1.49 & 1,137 & 0.22 & & & & \\
\hline Species identity & & 7.19 & 14,137 & $<0.0001$ & & 7.00 & 14,139 & $<0.0001$ \\
\hline \multicolumn{9}{|c|}{ Feather wear in relation to feather pigmentation (within-nests Repeated Measures) (2). } \\
\hline Pigm & & 3.32 & 1,120 & 0.071 & & 4.34 & 1,122 & 0.039 \\
\hline Pigm x Mesophilic bacteria & & 4.27 & 1,120 & 0.041 & & 6.99 & 1,122 & 0.009 \\
\hline Pigm $x$ Enterobacteriacea & & 6.03 & 1,120 & 0.015 & & 5.52 & 1,122 & 0.020 \\
\hline Pigm x Staphylococci & & 1.78 & 1,120 & 0.184 & & & & \\
\hline Pigm x Enterococci & & 0.05 & 1,120 & 0.823 & & & & \\
\hline Pigm $x$ Species identity & & 6.22 & 9,120 & $<0.0001$ & & 6.70 & 9,122 & $<0.0001$ \\
\hline \multicolumn{9}{|c|}{ Feathers degradability (3) } \\
\hline Mesophilic bacteria & $0.175(0.110)$ & 2.53 & 1,136 & 0.114 & $0.190(0.106)$ & 3.17 & 1,137 & 0.077 \\
\hline Enterobacteria & $0.181(0.112)$ & 2.60 & 1,136 & 0.109 & $0.196(0.109)$ & 3.24 & 1,137 & 0.074 \\
\hline Staphylococci & $-0.229(0.103)$ & 4.94 & 1,136 & 0.028 & $-0.211(0.096)$ & 4.79 & 1,137 & 0.030 \\
\hline Enterococci & $0.056(0.111)$ & 0.26 & 1,136 & 0.614 & & & & \\
\hline \multicolumn{9}{|c|}{ Wear of melanised feathers and feather degradability (4) } \\
\hline Mesophilic bacteria & $0.590(0.432)$ & 1.86 & 1,119 & 0.175 & & & & \\
\hline Enterobacteria & $-0.191(0.193)$ & 0.98 & 1,119 & 0.325 & & & & \\
\hline Staphylococci & $-0.345(0.193)$ & 3.18 & 1,119 & 0.077 & $-0.328(0.185)$ & 3.15 & 1,121 & 0.078 \\
\hline Enterococci & $-0.373(0.209)$ & 3.20 & 1,119 & 0.076 & $-0.355(0.188)$ & 3.54 & 1,121 & 0.062 \\
\hline Feather degradability & $0.238(0.102)$ & 5.47 & 1,119 & 0.021 & $0.241(0.098)$ & 5.98 & 1,121 & 0.016 \\
\hline
\end{tabular}


Table 3: Results from General Linear Mixed Models exploring the effects of age (fledglings vs adults) and species identity explaining feather wear and degradability by keratinolytic bacteria. The main effects were estimated in models that did not include the interaction, and the interaction was estimated in models that also included main effects. Since feather wear was estimated from several nestlings of the same nest, we included nest identity nested within the interaction between species and age as a random factor. Moreover, since estimates of feather degradability depend of feather mass, we included such information as a covariable in the model.

Factors

\begin{tabular}{lcccccc}
\hline & Effect & $\begin{array}{c}\text { Ms } \\
\text { effect }\end{array}$ & $\begin{array}{c}\text { MS } \\
\text { error }\end{array}$ & df & F & P \\
\cline { 1 - 4 } Feather wear & F & 15.96 & 0.62 & $6,211.4$ & 25.64 & $<0.0001$ \\
Species & F & 0.01 & 0.57 & $1,280.9$ & 0.01 & 0.923 \\
Species * Age & F & 0.81 & 0.56 & $6,313.0$ & 1.45 & 0.197 \\
Nest id(Species*Age) & Rnd & 0.66 & 0.37 & 168,1706 & 1.99 & $<0.0001$ \\
& & & & & & \\
Feather degradability & & & & & & \\
Feather mass & F & 4.28 & 0.27 & 1,101 & 15.89 & 0.0001 \\
Species & F & 2.12 & 0.27 & 5,101 & 11.99 & $<0.0001$ \\
Age & F & 3.14 & 0.27 & 1,101 & 30.85 & 0.0009 \\
Species * Age & F & 0.98 & 0.27 & 5,96 & 4.23 & 0.0016 \\
\hline
\end{tabular}


Figure legends:

Fig. 1: Wear of melanised and non-melanised parts of secondary-covert wing feathers (A), feather degradability in terms of feather keratine degradability (B), and nest bacterial environment (C) estimated as density of mesophilic bacteria (TSA), enterobacteria (HK), staphylococci (VJ) and enterococci $(\mathrm{KF})$. Values are averages $\pm 95 \% \mathrm{CI}$ and species are ordered from the highest to the lowest value of each of the considered variables (density of mesophilic bacteria in the case of nest bacterial environment).

Fig 2: Association between feather wear of melanised feathers and nest bacterial environment estimated as densities of mesophilic bacteria and enterobacteria. Bacterial load and wear values are corrected for species identity. Lines are regression lines.

Fig 3: Wing feathers wear and degradability of 7 and 6 species, respectively, with information for fledging (filled dots) and adult (open circles) birds. Values are Least square means $\pm 95 \%$ CI. Species are ordered from the largest to lowest fledglings' values of the considered variable. 
Fig. 1
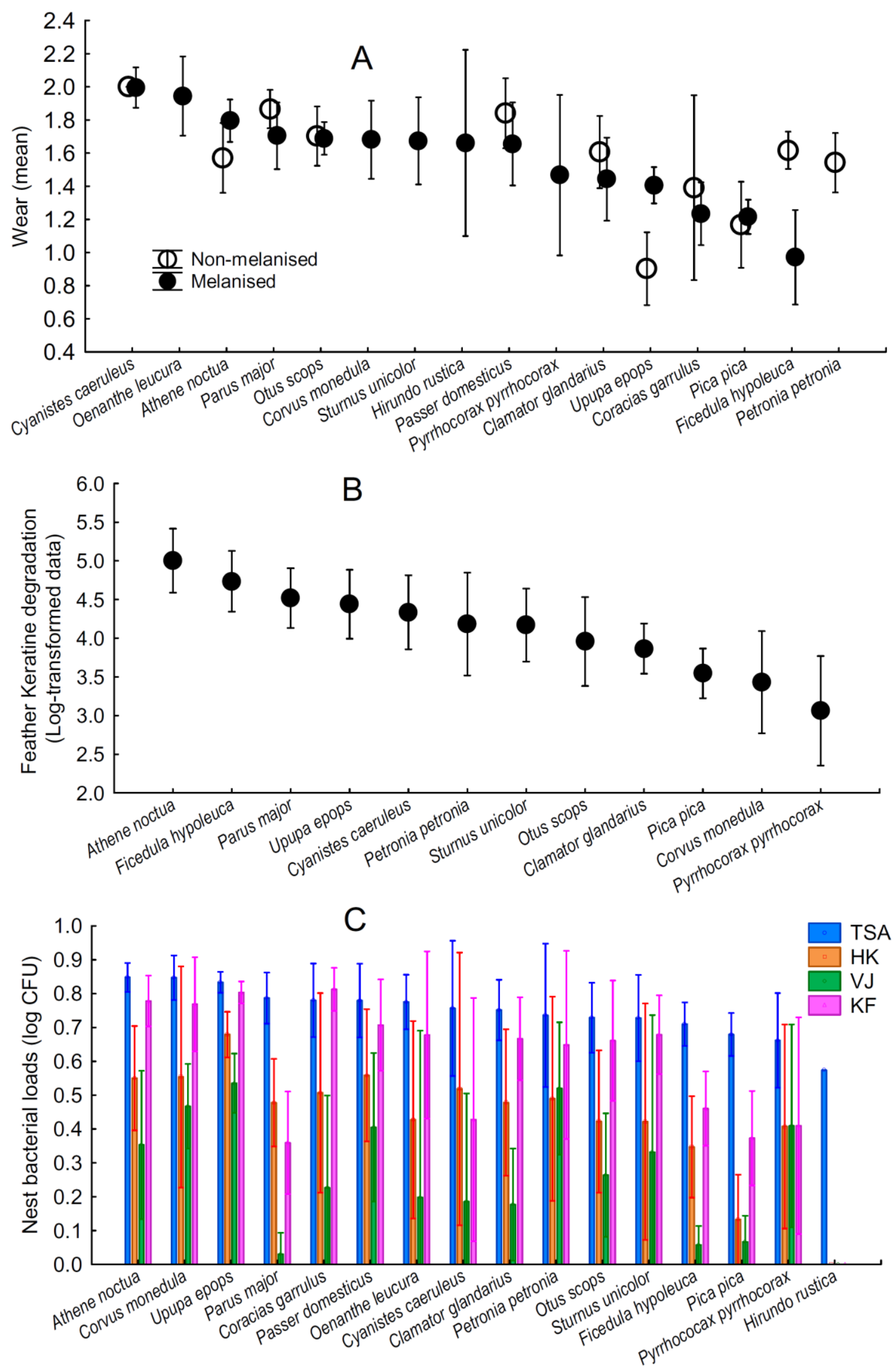
Fig 2.

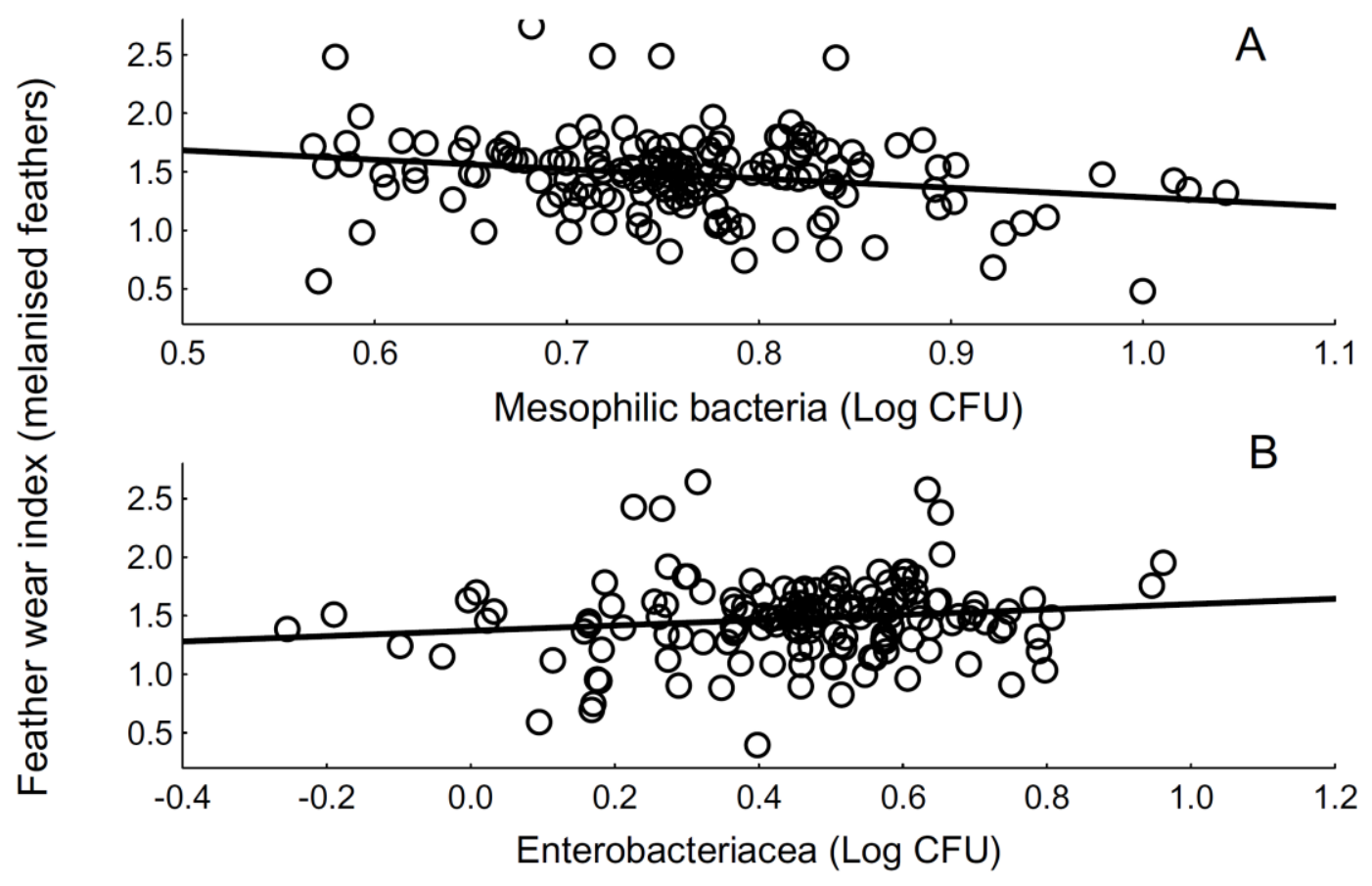


Fig. 3
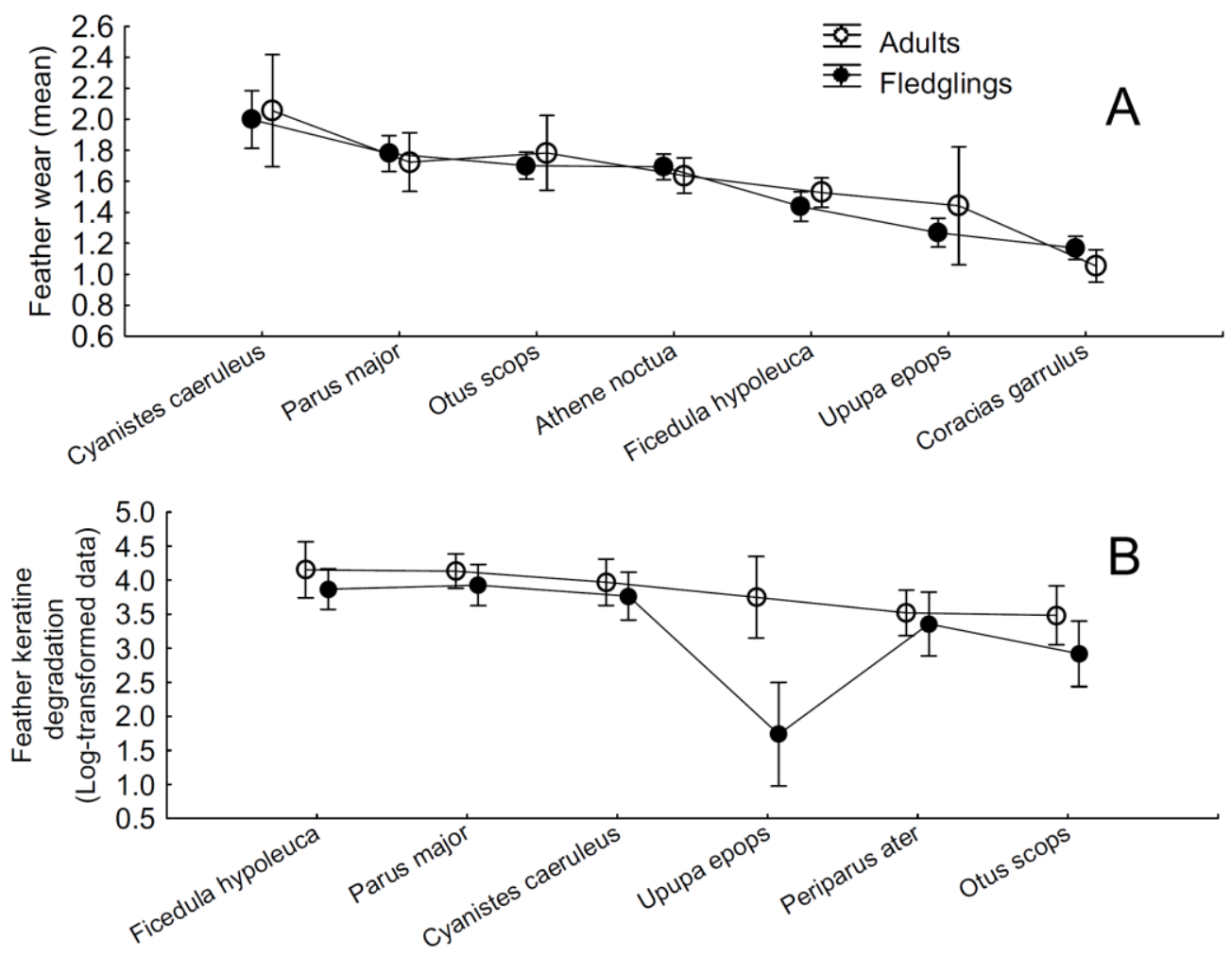
ESM Table 1: Results from PGLM models exploring the effects of nest bacterial environment (estimated as density of mesophilic bacteria, enterobacteria, staphylococci and enterococci) on (1) wear of melanised feathers (2), and feather degradability (3) after correcting for phylogeny. We also explored the effect of both bacterial environment and feather degradability on wear of melanised (4) and non-melanised (5) feathers. For all the analyses, we used average species values, which were weighted by sample size $(1 / \mathrm{N})$. We estimated effect sizes (Cohen's $d$ ) and power associated to independent factors in each of the models.

Full models

\begin{tabular}{|c|c|c|c|c|c|c|}
\hline & B (SE) & $\mathrm{t}$ & $\overline{\mathrm{df}}$ & $\overline{\mathrm{P}}$ & Effect size & Power \\
\hline \multicolumn{7}{|c|}{ Wear of melanised feathers (1) } \\
\hline Mesophilic bacteria & $3.887(2.612)$ & 1.49 & 10 & 0.17 & 0.112 & 0.217 \\
\hline Enterobacteria & $-0.617(1.166)$ & 0.53 & 10 & 0.61 & 0.015 & 0.072 \\
\hline Staphylococci & $1.001(0.960)$ & 1.05 & 10 & 0.32 & 0.255 & 0.424 \\
\hline Enterococci & $-0.656(1.000)$ & 0.66 & 10 & 0.53 & 0.205 & 0.354 \\
\hline \multicolumn{7}{|c|}{ Wear of non-melanised feathers (2) } \\
\hline Mesophilic bacteria & $-1.975(3.268)$ & 0.60 & 6 & 0.57 & 0.136 & 0.179 \\
\hline Enterobacteria & $1.926(1.435)$ & 1.34 & 6 & 0.23 & 0.393 & 0.417 \\
\hline Staphylococci & $-2.298(1.046)$ & 2.20 & 6 & 0.071 & 0.665 & 0.619 \\
\hline Enterococci & $0.814(1.235)$ & 0.66 & 6 & 0.53 & 0.511 & 0.512 \\
\hline \multicolumn{7}{|c|}{ Feather degradability (3) } \\
\hline Mesophilic bacteria & $1.527(4.270)$ & 0.358 & 7 & 0.73 & 0.008 & 0.058 \\
\hline Enterobacteria & $1.594(1.925)$ & 0.828 & 7 & 0.44 & 0.098 & 0.156 \\
\hline Staphylococci & $-2.330(1.726)$ & 1.35 & 7 & 0.22 & 0.378 & 0.451 \\
\hline Enterococci & $0.959(1.909)$ & 0.50 & 7 & 0.63 & 0.059 & 0.113 \\
\hline \multicolumn{7}{|c|}{ Wear of melanised feathers and feather degradability (4) } \\
\hline Mesophilic bacteria & $3.226(3.101)$ & 1.04 & 5 & 0.35 & 0.056 & 0.090 \\
\hline Enterobacteria & $0.569(1.456)$ & 0.39 & 5 & 0.71 & 0.066 & 0.098 \\
\hline Staphylococci & $-0.096(1.492)$ & 0.06 & 5 & 0.95 & 0.004 & 0.053 \\
\hline Enterococci & $-0.361(1.429)$ & 0.25 & 5 & 0.81 & 0.000 & 0.050 \\
\hline Feather degradability & $-0.324(0.278)$ & 1.16 & 5 & 0.30 & 0.195 & 0.192 \\
\hline
\end{tabular}

Wear of non-melanised feathers and feather degradability (5)

$\begin{array}{lcccccc}\text { Mesophilic bacteria } & 2.099(4.159) & 0.50 & 3 & 0.65 & 0.226 & 0.130 \\ \text { Enterobacteria } & 1.765(1.801) & 0.98 & 3 & 0.40 & 0.327 & 0.164 \\ \text { Staphylococci } & -2.372(1.809) & 1.31 & 3 & 0.28 & 0.176 & 0.113 \\ \text { Enterococci } & 0.881(2.033) & 0.43 & 3 & 0.69 & 0.392 & 0.185 \\ \text { Feather degradability } & 0.036(0.342) & 0.10 & 3 & 0.92 & 0.047 & 0.067\end{array}$


ESM Fig 1. Means \pm CI 95\% of oligopeptide concentration after 21 days of incubation of control tubes containing only buffer, the buffer plus the degrading bacteria Bacillus licheniformis, the buffer plus a piece $\left(1 \mathrm{~cm}^{2}\right)$ of feather, or the buffer plus the bacteria plus the piece of feather.

Fig. 1

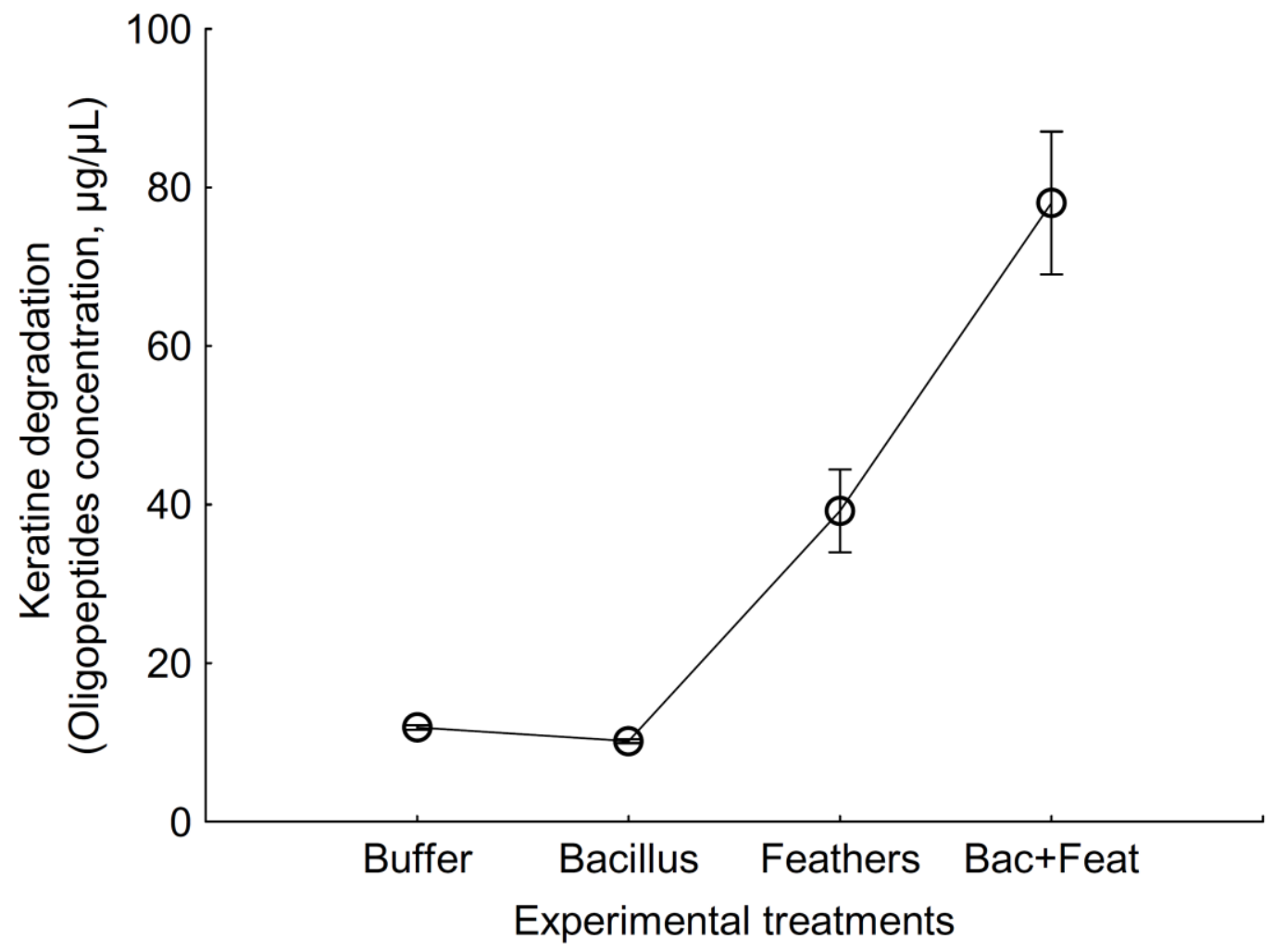

